\title{
THE PECULIARITIES OF THE VEGETATIVE REGULATION OF THE HEART RHYTHM IN PROCESSING DIFFERENT MODALITY AND SPEED INFORMATION OF PRESENTING IRRITATORS
}

Introduction. The mental activity brain mechanisms are the object of many studies in psychophysiology. The mental activity vegetative providing participation regulation and evaluation problem by the indications of the heart rhythm while processing various information is considered one of the most important tasks.

Purpose. The aim of our study was to find out the heart rhythm vegetative regulation peculiarities while processing different modality information and presentation speed.

Methods. In the experimental study participated 30 men aged 19 to20. The study was held using computer-aided devices "Diagnost1M» and «Cardiolab». In the background and while doing tasks with different presenting information speed on the heart rhythm variability indications different modality registration irritators was held (the average meaning of the HRF, mode (Mo), mode amplitude (AMo), standard deviation of the cardio-intervals massive (SDNN), stress index (SI)).

Result. It has been proved, that while the processing verbal and image information speed growing the heart rhythm regulatory mechanisms activation level gradually increases and decreases on condition of the irritators tempo presentation decrease. When processing information on verbal stimuli at all speeds, the heart rate indicators were somewhat higher than the presentation of figures

Conclusion. It has been found, that the heart rhythm vegetative regulation peculiarities depend on the speed of presenting irritators and do not depend on the signal modality.

Key words: heart rhythm variability, the first and the second signal brain systems, information processing, reverse

The problem setting. In psychophysiology the brain mechanisms of the mental activity are considered as essential elements of the brain's integrative activity and are the result of many studies. The heart work state control can give the notion of functional abilities of the organism and "the physiological price" of one or another mental activity kind [1]. The most informative here are the indications of the heart rhythm variability, which can serve the objective characteristic of the mental activity tenseness [2]. The meaning of the HRV reflects vitally important indications of the organism's physiological functions management - the vegetative balance and the functional reserves of its management mechanisms $[3,4,5,6]$. All this leads to the increase of the nervous and emotional tenseness and is one of the reasons for arising illnesses. Thus the problem of the regulation and the evaluation of the participation of the vegetative mental activity provision (by the HR indications) in processing information and its mechanisms is considered one of the most important tasks of psychophysiology and applied sciences [7]. We assume that the results and mechanisms of the heart rhythm for the processing of information in the form of figures and verbal stimuli may be different.

The aim - to clear out the peculiarities of the heart rhythm vegetative regulation in processing different modality and speed information's presenting.

\section{The research methodology and organization}

30 people (average age 20,4 $\pm 1,2$ years) were tested mental workability on a computer device "Diagnost1M" with reverse in an "assertive rhythm" regime [8, 9, 10]. The main research was begun with figures at a speed of 30 irritators in 1 minute. Then we proceeded to the speed of 60, 90 and 120 and farther in the same succession the speed decreased. We finished the work on the speed of 30 irritators in 1 minute. After a short rest mental work with reverse repeated, but for the information processing verbal stimuli were used. 
In the background and while doing tasks with different speed of the information presenting on the irritators of different modality we held registration of the heart rhythm variability indications with the help of the "Cardiolab" device. The heart rhythm statistic indications: average HRF meaning, mode (Mo), mode amplitude (AMo), cardio-intervals massive standard deviation (SDNN), stress index (SI) were defined.

The research results were processed with the use of statistic programs Statgraphics, Microsoft Excel.

\section{The research results and their discussion}

The statistics analysis of the students' heart rhythm in doing tasks with different tempo of the information presenting found out truthful differences of the HRV indications in the active state if compared to the state of statics, as well on presenting figures as on presenting verbal stimuli. (tabl.1).

Table 1

The results of the vegetative provision of the work in test on the information processing in the closed cycle on presenting geometric figures and verbal stimuli

\begin{tabular}{|c|c|c|c|c|c|c|c|}
\hline \multirow{2}{*}{\multicolumn{2}{|c|}{$\begin{array}{c}\text { Speed, } \\
\mathrm{V}, \mathrm{br} / \mathrm{min} .\end{array}$}} & \multirow{2}{*}{ Irritator type } & \multicolumn{5}{|c|}{ Researched indications } \\
\hline & & & $\begin{array}{l}\text { Time, } \\
\text { in } / \mathrm{min}\end{array}$ & $\begin{array}{l}\text { Mo, } \\
\text { S }\end{array}$ & $\begin{array}{c}\text { Амо } \\
\%\end{array}$ & $\begin{array}{c}\text { SDNN, } \\
\mathrm{s}\end{array}$ & $\begin{array}{l}\text { SI, } \\
\text { c.u. }\end{array}$ \\
\hline \multicolumn{2}{|c|}{ Background } & words/figures & $67,3 \pm 1,5$ & $870,6 \pm 18,4$ & $33,3 \pm 1,6$ & $61,5 \pm 3,2$ & $46,3 \pm 3,5$ \\
\hline \multirow[b]{2}{*}{$\mathbf{V}_{1}$} & \multirow[b]{2}{*}{30} & words & $65,3 \pm 1,2$ & $848,4 \pm 20,0$ & $33,5 \pm 1,7$ & $61,1 \pm 4,1$ & $63,0 \pm 5,7 \#$ \\
\hline & & figures & $66,8 \pm 1,4$ & $827,8 \pm 22,5$ & $31,5 \pm 1,2$ & $63,3 \pm 3,3$ & $55,5 \pm 4,3^{*}$ \\
\hline \multirow[b]{2}{*}{$\mathbf{V}_{2}$} & \multirow[b]{2}{*}{60} & words & $68,5 \pm 1,5$ & $828,8 \pm 23,3$ & $35,9 \pm 2,8$ & $52,1 \pm 3,3 \#$ & $71,0 \pm 5,0 \#$ \\
\hline & & figures & $68,8 \pm 1,3$ & $807,1 \pm 22,9 *$ & $41,4 \pm 2,0$ & $49,4 \pm 2,7^{*}$ & $64,0 \pm 5,9 *$ \\
\hline \multirow{2}{*}{$\mathbf{V}_{3}$} & \multirow{2}{*}{90} & words & $69,0 \pm 1,5$ & $843,5 \pm 23,7$ & $37,1 \pm 1,8$ & $52,8 \pm 3,3$ & $66,4 \pm 5,7 \#$ \\
\hline & & figures & $70,9 \pm 1,5$ & $779,2 \pm 21,9 *$ & $37,3 \pm 1,9$ & $54,9 \pm 3,8$ & $69,1 \pm 6,5^{*}$ \\
\hline \multirow[b]{2}{*}{$\mathbf{V}_{4}$} & \multirow[b]{2}{*}{120} & words & $71,5 \pm 1,7 \#$ & $802,9 \pm 24,8 \#$ & $34,9 \pm 1,4$ & $64,0 \pm 3,2$ & $72,9 \pm 5,6 \#$ \\
\hline & & figures & $71,3 \pm 1,8^{*}$ & $809,4 \pm 19,0 *$ & $37,4 \pm 1,7$ & $60,5 \pm 3,7$ & $70,9 \pm 5,8^{*}$ \\
\hline \multirow[b]{2}{*}{$\mathbf{V}_{5}$} & \multirow[b]{2}{*}{90} & words & $69,9 \pm 1,8$ & $828,8 \pm 24,9$ & $36,3 \pm 1,8$ & $52,8 \pm 3,3$ & $73,1 \pm 6,7 \#$ \\
\hline & & figures & $69,6 \pm 1,5$ & $820,3 \pm 21,9$ & $36,7 \pm 1,9$ & $60,5 \pm 3,7$ & $70,6 \pm 6,5^{*}$ \\
\hline \multirow[b]{2}{*}{$\mathbf{V}_{7}$} & \multirow[b]{2}{*}{60} & words & $69,5 \pm 1,6$ & $832,4 \pm 25,1$ & $35,7 \pm 1,6$ & $61,5 \pm 3,8$ & $64,2 \pm 4,9 \#$ \\
\hline & & figures & $69,4 \pm 1,7$ & $848,6 \pm 22,3$ & $36,0 \pm 1,9$ & $57,7 \pm 4,3$ & $55,8 \pm 5,6$ \\
\hline \multirow[b]{2}{*}{$\mathbf{V}_{8}$} & \multirow[b]{2}{*}{30} & words & $66,8 \pm 1,8$ & $842,9 \pm 25,3$ & $38,3 \pm 1,9$ & $57,3 \pm 3,3$ & $62,7 \pm 5,6 \#$ \\
\hline & & figures & $67,0 \pm 2,5$ & $848,6 \pm 21,7$ & $34,9 \pm 1,7$ & $60,5 \pm 3,7$ & $50,6 \pm 4,4$ \\
\hline
\end{tabular}

Note: $*_{-} \mathrm{p}<0,05$ between the background meaning of the indication and its meaning in doing tasks on presenting figures; \#- $\mathrm{p}<0,05$ - on presenting words.

It is seen from table 1, that in the different modality information processing, compared to the static state (background) such indications of the heart rhythm variability, as HRF, AMo, SI gradually increased and were in dependence from the speed of the irritators presenting, while the speed increase they increased, and on condition of the signals giving speed decrease they decreased, such changes occur both on figures and the words.

The meanings of the indications Mo and SDNN decreased in relation to the background indications. The least meanings of the indications were registered in doing the work at the speed of presenting 120 irritators in 1 minute. Such regularity was outlined both on presenting figures and on the verbal stimuli.

The decrease of the heart rhythm variability while the work at high speeds of the information presenting witnesses the increase of the role of the central regulation mechanisms and 
tenseness of the heart work on account of sympato-adrenal vegetative nervous system [2]. We can admit, that the maximum level of the regulation mechanisms tenseness is remarked at the speed of presenting 120 irritators in 1 minute. On condition of the verbal stimuli processing the tenseness of the regulation mechanisms of the heart rhythm variability is a little greater (while probable differences were not found), than on figures. More expressive it is remarked at the low speed of signals presenting (30-60) and is leveled on the high speed (90-120) and in the background.

The obtained results witness the fact, that there exist differences in power of the heart rhythm between all kinds of the mental activity in the comparison of the active states with the static state. We can remark, that in processing information to verbal stimuli at all speeds the heart rhythm indications were a little higher than on presenting figures. It can witness, that the second signal system of the head brain bark switches to the work.

The results of the heart rhythm variability research revealed changes of a number of time oscillatory characteristics of the heart rhythm variability, witnessing the decrease of the modulation of the parasympathetic and the increase of the sympato-adrenal activity of the autonomic heart regulation in differentiating and processing information in the Go/NoGo/Go regime if compared to the background HRV indications.

In the heart rhythm regulation mechanisms in processing information at the speed of presenting 120 irritators in 1 minute in the $\mathrm{Go} / \mathrm{NoGo} / \mathrm{Go}$ regime prevailed the defensive type of the heart rhythm regulation, it being confirmed truthfully by the less HRF increase, SI, and highfrequency breathing modulation power oppression. The pointed reactions complex, probably characterizes dissipated attention oriented on freeing spontaneous information from the memory [11].

Thus, the main physiological mechanisms of adopting to the conditions of psychomotor activity in processing different complexity information is the dependence of the heart rhythm regulation mechanisms on doing the task on information processing complexity, and also gradual increase of the heart rhythm central regulatory mechanisms participation and simultaneous decrease of the variability and the autonomous regulation participation in presenting irritators with the speed from $30-60$ irritators in 1 minute to presenting 90 and 120 irritators in 1 minute.

In figure, changes SI in processing information of different modality with different irritators' presenting speed are presented. We established, that beginning from the static state (background) SI indication (stress of index) increased while the speed increase and decreased while its decrease (Fig).

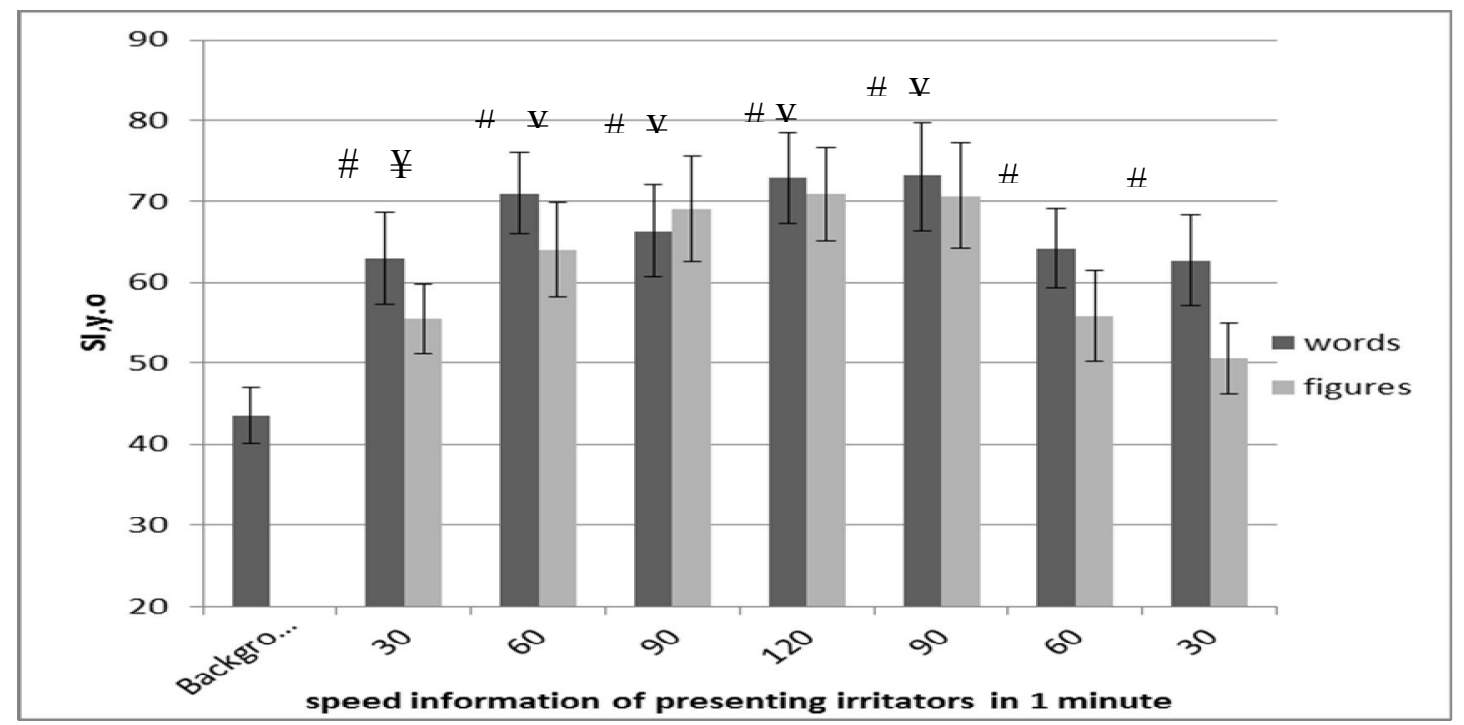

Fig. SI changes in processing different modality information with different irritators presenting compared with the background.

Note: $*_{-}-\mathrm{p}<0,05$ speed on condition of differentiating figures; \#-p<0,05 on condition of differentiating words. 
It is seen from figure 1, that the indication of the stress index in the static sate (background) as well on presenting figures as on words was equal $(46,3)$. With gradual increase of the speed indication SI truthfully increases on all speeds $(\mathrm{p}<0,05)$. At the speed of presenting 30 irritators in 1 minute on figures it increased to 66,8 , and on the words - to 65,3. At the speed of presenting 60 irritators in 1 minute on figures indication SI was 68,8 and 68,5 on the words.

At the speed of presenting 90 irritators in 1 minute the results of the indication on the figures were 70,9, while on the words $-69,0$. The speed having increased to presenting 120 irritators in 1 minute the meaning of the stress index indication reached the highest meanings, it was 71,3 on the figures, and 71,5 on the words. With the speed decreased SI indication gradually decreases. Truthful differences were not found between signals modality.

Thus, on condition of the gradual increasing of the speed of processing verbal and image information the level of the heart rhythm regulatory mechanisms activation by the autonomous nervous system gradually increases and decreases on condition of decreasing the tempo of the irritators' presenting.

\section{Conclusions:}

1.Peculiarities of the heart rhythm regulation by the autonomous nervous system are in dependence on the speed of presenting irritators and do not depend on the modality of the signals presented.

2.On condition of the gradual increasing of the speed of processing verbal and image information the level of the heart rhythm regulatory mechanisms activation by the autonomous nervous system gradually increases and decreases on condition of decreasing the tempo of the irritators' presenting.

3.A high level of the mechanisms' regulation activation by the autonomous nervous system of the heart rhythm was registered while presenting irritators at the speed of 90-120 irritators in 1 minute, and a low one in the state of rest and at the speed of 30-60 irritators in 1 minute.

4. In case of presenting signals of different modality by the HRV indications probable differences of the heart rhythm regulatory mechanisms' activation level on the mental loading in the reverse $(\mathrm{P}>0,05)$ were not found. Inconsiderable prevailing of the heart rhythm mechanisms' regulation activation level of the people diagnosed on condition of processing information in the second signal system is remarked.

\section{References (in language original)}

1. Ардашев А.В., Лоскутов А.Ю. Практические аспекты современных методов анализа вареабельности сердечного ритма: медпрактика. М, 2010. 126 с.

2. Баевский Р.М., Кудрявцева В.Н. Особенности регулирования сердечного ритма при умственной работе: Физиол. человека. 1975.т. 1 №2. 296-301 с.

3. Баевский Р.М., Иванов. Г.Г., Чирейкин Л.В. Анализ вареабельности сердечного ритма при использовании различных элэктрокардиографических систем (часть 1) Вестник аритмологии. - 2000. №24. 9-24 с.

4. Коваленко С. О., Кудій Л.І. Варіабельність серцевого ритму: методичні аспекти. Черкаси. ЧНУ ім. Б. Хмельницького, 2016. -298 с.

5. Akselrod S., Armonk. N.Y. Components of heart rate variability. 1995. 146-164 p.

6. Houle M.S.,Billman G.E. Low - frequency component of the heart rate variability spectrum: a poor marker of sympathetic activity: Am. J. Physiol. 1999. 276 p.

7. Иваницкий А.М., Портнова Г.В., Мартынова О.В. Картирование мозга при вербальном и пространвенном мышлении: журнал высшей нервной деятельности человека. 2013. Т. 63. № 6. .677 - 686 с.

8. Лизогуб В.С. Черненко Н.П., Палабіїк А.А., Безкопильна С.В. Спосіб визначення розумової працездатності за умови переробки інформації з різною швидкістю пред'явлення подразників: вісник Черкаського університету. Серія «Біологічні науки». 2018. - №1 (335). 74-84 с.

9. Макаренко М. В. Методика проведення та оцінки індивідуальних нейродинамічних властивостей вищої нервової діяльності людини: фізіологічний журнал. 1999. Т.45. №4. 123-131 с.

10. Лизогуб В. С. Черненко Н. П., Кожемяко Т. В Переробка інформації різної складності та модальності особами 3 різними індивідуально-типологічними властивостями ВНД. Вісник Черкаського університету. Вип. 71. Черкаси, 2005. 60 - 67 с.

11. Черненко Н.П. Вегетативне забезпечення розумової діяльності людей з різними індивідуальнотипологічними властивостями вищої нервової діяльності (дисертація). Київський національний університет Тараса Шевченка.2013. 


\title{
References
}

1. Ardashev A.V., Loskutov A.Y. (2010) Practical aspects of the contemporary methods of the heart rhythm variability analysis. Medpractice. M. - 126 (in Rus).

2. Baevskij R.M., Kudryavtseva V.N. (1975) The heart rhythm regulation peculiarities in mental work. Fyzyolohyia cheloveka [Human physiology]. - V.1. №2. 296-301 (in Rus).

3. Baevskij R.M., Ivanov G.G., Chirejkin L.V. (2000) The heart rhythm variability analysis in using various electric-cardio-graphic systems (part 1) Visnyk aritmologii [Arythmology bulletin].№ 24. .9-24 (in Rus).

4. Kovalenko S. O., Kudii L. I. (2016). Heart Rate Variability. Methodical aspects. Cherkasy: Cherkas'kyy natsional'nyy universytet im. B. Khmel'nyts'koho. 298 (In Ukr.)

5. Akselrod S., Armonk N.Y.(1995). Components of heart rate variability.146-164

6. Houle M.S.,Billman G.E.(1999). Low - frequency component of the heart rate variability spectrum: a poor marker of sympathetic activity: Am. J. Physiol. 276.

7. Ivanitsky, A.M., Portnova, G.V., Martynova, O.V. [etc.]. (2013). Mapping the brain in verbal and spatial thinking. Zhurnal vyisshey nervnoy deyatelnosti cheloveka [Journal of Higher Nervous Activity of human]. 63(6), 677 - 686. (in Rus).

8. Lyzohub V.S., Chernenko N. P., Palabijik A. A., Bezkopylna S. V. (2018) Method of definitions mental performance during processing of information with different speed of presentation of stimuli. Visnyk Cherkaskoho universytetu [Cherkasy university bulletin: biological sciences series] №1 (335). . 74-84 (in Ukr)

9. Makarenko, M. V. (1999). Method of estimation of individual neurodynamic characteristics of higher nervous activity in man. Fiziolohichnyi zhurnal (Physiological journal). 45 (4), 123-131 (in Ukr.)

10. Lyzohub, V.S., Chernenko, N.P., Kozhemiako, T.V. (2005). Processing information of varying complexity and modality by individuals with different individual-typological properties of HNP. Visnyk Cherkaskoho universytetu. [Cherkasy university bulletin: biological sciences series]. 71, 60 - 67. (in Ukr)

11. Chernenko N.P. (2013). Vegetative provision of mental activity of people with different individualtypological properties of nervous activity. (PhD dissertation). Taras Shevchenko National University of Kyiv. (in Ukr)

Анотація. Безкопильна С. В., $\quad$ Палабї̈к А. А., Кандиба П. О. вегетативної регуляції серцевого ритму під час переробки інформації різної модальності та швидкості пред'явлення подразників.

Проблематика. Мозкові механізми розумової діяльності $е$ предметом багатьох досліджень у психофізіології. Проблема регулячії та очінки участі вегетативного забезпечення розумової діяльності за показниками серцевого ритму під час переробки різноманітної інформачї вважається однією із найважливіших завдань.

Метою натого дослідження було з'ясувати особливості вегетативної регулящії серцевого ритму під час переробки інформаџї різної модальності та швидкості пред'явлення.

Методи дослідження. В експериментальному дослідженні приймали участь 30 чоловіків 19-20-річного віку. Дослідження поводили з використанням комп'ютеризованих пристроїв «Діагност1M» та "Cardiolab». У фоні та під час виконання завдань з різною швидкістю пред'явлення інформаиії на подразники різної модальності проводили реєстрацію показників варіативності сериевого ритму (середнє значення ЧСС, мода (Мо), амплітуда моди (АМо), стандартне відхилення масиву кардіоінтервалів (SDNN), стрес індекс (SI)).

Основні результати дослідження. Встановлено, що особливості вегетативної регуляиії серчевого ритму знаходяться в залежності від швидкості пред'явлення подразників $i$ не залежать від модальності сигналу.

Висновки. Доведено, щз під час зростання швидкості переробки вербальної та образної інформачії рівень активачї регуляторних механізмів серцевого ритму поступово зростає $i$ знижується за умови зменшення темпу пред'явлення подразників.

Ключові слова: варіабельність сериевого ритму, перша та друга сигнальні системи мозку, переробка інформації, реверс

\section{Науково-дослідний інститут фізіології імені М.Босого Черкаського національного університету імені Б.Хмельницького Черкаський Державний Технологічний університет}

\author{
Одержано редакцією \\ 27.03.2018 \\ Прийнято до публікації \\ 25.10.2018
}

